\title{
DEVELOPMENT OF DISTANCE TECHNOLOGIES IN PHYSICAL EDUCATION OF STUDENTS: OPPORTUNITIES AND CHALLENGES
}

\author{
Viktor Koryahin $^{1 \mathrm{ABCD}}$, Oksana Blavt ${ }^{1 \mathrm{ABCD}}$ \\ ${ }^{1}$ Lviv Polytechnic National University \\ Authors' Contribution: A - Study design; B - Data collection; C - Statistical analysis; D - Manuscript Preparation; E - Funds Collection
}

DOI: $10.17309 /$ jltm.2021.1.01

\begin{abstract}
Purpose. To identify the state of teaching "Physical Education" by means of distance technologies at the university. Materials and methods. The study involved 3,726 first-year students of the Lviv Polytechnic National University of all educational-and-scientific institutes. The organization of the study was aimed at studying the opinion of students on various issues regarding the quality of distance education in physical education. At the empirical level of the study, a questionnaire was used.

Results. The study analyzed the state of physical education at the university by means of distance learning. According to the results of the survey, it was found that the vast majority of surveyed students $(81.3 \%)$ believe that physical education classes by means of distance learning are necessary in the conditions of introduction of quarantine safety measures. $51.6 \%$ of students noted that methodical skills gained during the classes significantly helped them in organizing independent physical training sessions during the suspension of educational activities in auditoriums. $71 \%$ support the possibility of physical education classes by means of distance technologies in order to counteract the forced restriction of motor activity.

Conclusions. Ensuring the effectiveness of physical education of students in the position of quarantine measures requires new approaches and methods of interaction with students, adequate choice of goals and objectives, organizational forms, methods and means of physical education maintain the proper level of their motor activity and prevent social maladaptation. From the study, we can conclude that physical education by means of distance technologies is in a state of development, but not at such a rapid pace. Instead, on the basis of the study summarizes that the use of distance learning means in physical education of students ensures the formation of values of a healthy lifestyle and maintaining their health at the appropriate level.
\end{abstract}

Keywords: physical education, student, distance technology, quarantine.

\section{Introduction}

The situation related to COVID-19 caused the decision to temporarily suspend students' educational activities as usual. In the system of higher professional education in Ukraine, including in the physical education of university students, a problem that requires immediate solution developed. Based on paragraph 4.2 of the Regulation on distance learning, approved by the Order of the Ministry of Education and Science of Ukraine no. 466 of April 25, 2015, during the quarantine, educational institutions can organize an educational process using distance education technologies (Bezgrebelna, Pavlos, Bulatov, \& Nezgoda, 2020).

The transition to distance learning at the university caused a change in the way and rhythm of life, as a result of which all the time students are forced to spend only on

(c) Koryahin, V., Blavt, O., 2021. mental activity in a sitting position. Lack of physical activity for quite a long time, inevitably has a negative impact on health. As a consequence, the overall state of the body and mood deteriorates that leads to a decrease in immunity, occurrence and exacerbation of diseases. As a result, there is a situation where "we teach at the expense of health". In the conditions of implementation of quarantine measures, when all the time students are forced to spend only on mental activity, this becomes extremely relevant.

Taking into account the fact that the preservation and strengthening of students' health is one of the main tasks of our state's social program (Koryahin, Blavt, \& Tsiovkh, 2018), the University, fulfilling the public order, is trying to counteract the negative consequences of forced restriction of motor activity of students. In the conditions of the implementation of quarantine measures, the physical education of students is the main factor of a healthy lifestyle (Bergier, Tsos, \& Bergier 2014). 
It is determined (Kensitskaya, 2017), that physical education under these conditions, is the main means of enabling students to gain a certain stock of knowledge and skills to apply them in practice to counteract the health consequences of a sedentary lifestyle of students, aimed at improving social, mental, emotional and physical dimensions. Meanwhile, the World Health Organization emphasizes, "every movement is beneficial, and physical activity of any type can improve health and well-being, and the more, the better." (Daskapan, Tuzun, \& Eker, 2005).

Current regulations state that the regularity of motor activity of university students is due to the conduct of classes in the discipline "Physical Education" (Gladoschuk, 2018). It is determined that the purpose of physical education now is to form an idea about the use of all possible forms of physical culture adapted to today's realities to ensure compliance with the regime of physical mobility, as much as possible but obeying quarantine safety measures (Bezgrebelna, Pavlos, Bulatov, \& Nezgoda, 2020).

The problem of ensuring the proper level of physical education of students is currently receiving increased attention of specialists (Anikieiev, 2015; Pekmezovic, Popovic, Tepavcevic, Gazibara, \& Paunic, 2011), which is quite natural, given the fundamental changes in the social life of the country, which could not ignore the sphere of education. Because of changes in the model of functioning in society and sedentary lifestyle, the problem is very timely.

Scientists agree that at the present stage the problem of physical education of students in the education system is especially relevant (Dukh, 2011; Bergier, Tsos, \& Bergier 2014), because it allows timely and appropriate to respond to negative processes occurring due to radical change of lifestyle. It is proved (Extremera, \& Fernández-Berrocal, 2006; Fedorenko, Velichko, Stepkin, Chorna, \& Solovyov, 2019). that a properly organized process of physical education of students creates conditions for self-development and self-realization, is an important factor in strengthening immunity and maintaining the health of students.

According to researchers (Gevko \& Nevmerzhytska, 2019; Zelenskyi \& Zelenskyi, 2018), over the lately due to the changes in the characteristics of the working environment, the role of physical education of students has expanded beyond individual development, as the use of distance technologies resources has become a valuable tool for ensuring the proper level of teaching of physical education. These changes are accompanied by the corresponding growth and evolution of the complex of researches of distance learning tools at the intersection of many disciplines, such as education, information-and-communication technologies (ICT), learning resources management, organizational development, educational psychology, physical rehabilitation and more.

The chosen direction of research and the highlighted contradictions between the need for physical education classes by means of distance technologies and the opportunities of educating students' conscious attitude to their health as the highest social value, the formation of hygienic skills and principles of healthy living, the maintaining and strengthening of physical and mental health are the basis of an effective educational process (Daskapan, Tuzun, \& Eker, 2005; Dukh, 2011). Therefore, the issue of supporting and improving the health of future professionals as the main driver of progress in all spheres of the society and the state is considered one of the most relevant today.

The need of studying the experience gained during the academic year and, on the basis of this, outlining the trends in the development of distance technologies in physical education of students, which ensure a high level of teaching this discipline in the educational space of the higher school, awareness of their specifics and potential of extrapolation into modern educational reality led to the choice of the topic of research.

The study purpose was to identify the state of teaching "Physical Education" by means of distance technologies at the university.

\section{Materials and methods}

The implementation of scientific research requires effective application of a set of methods. Our research is a system of theoretical and empirical procedures. At the theoretical level, in particular, the method of analysis and synthesis is used to consider the research issues at the intersection of physical education, education and interdisciplinary research to use data for analyzing the relationships between pedagogical practices and learning outcomes.

We cannot ignore the synergetic approach to pedagogical research, which focuses on the analysis of the phenomenon of self-organization of students in the process of distance education.

Accordingly, it is also worth emphasizing the interdisciplinary approach, since in the context of our research it is important to take into account the position of pedagogy of physical education, development of innovative resources, ICT, sociology. This approach allows for a holistic analysis of the mechanisms of physical education by means of distance technology as a social, educational phenomenon, the result of which is the personal development of the student and increase the level of his physical education

In our study, an acmeological approach, which implies a special emphasis on the creative potential of students' personality, their self-realization and formation as a professional, plays an important role. The fundamental categories of pedagogical acmeology are skills and abilities, competence, creative potential, physical development of students.

Eventually, the use of the prognostic method allows developing scientific and methodological recommendations for their implementation in the practice of educational institutions, in the context of strategic areas of physical education of students.

At the empirical level of the study, a questionnaire was used as an exploratory (pilot) study to determine the role, structure, quality of work, accessibility, availability of presentation materials, use of appropriate teaching methods, etc.

The questionnaire was built on a simplified program, with a small amount of tools. The tools used included methodical documents, which were used to collect primary information: questionnaires, interview forms, cards for document analysis.

\section{Study participants}

The study involved 3,726 first-year students of the Lviv Polytechnic National University of all educational-and-scientific institutes. 


\section{Study organization}

The organization of the study was aimed at studying the opinion of students on various issues regarding the quality of distance learning in physical education and provided for:

- creation of a questionnaire with the possibility of saving an unlimited number of questions in it and answering every question;

- edition of documents (questionnaires) for surveys;

- $\quad$ setting the parameters of the survey: date and time of the survey, its duration, etc.);

- $\quad$ setting parameters for processing the results of the survey;

- $\quad$ uploading survey results to Excel

- consolidation of primary data from questionnaires;

- $\quad$ analysis of the data received;

- $\quad$ preparation of final data;

- summarizing of survey results and preparation of the report.

Collection of primary information from the questionnaire was provided with the help of mobile application, which provides an opportunity to conduct a survey with any number of students. Increasing the level of reliability of the study is ensured by the mobility of students and its independence from the availability of paper questionnaires. Therefore, they increased the number of respondents and helped to reduce the sampling error. The organization of delivery of questionnaires to students was simplified: the questionnaires were downloaded automatically and did not depend on their location.

Questions of the questionnaire before the start of the mass experiment were tested several times and, consequently, the necessary changes and adjustments were made. Particular attention was paid to ensuring the principle of objectivity. The reliability of the experimental results was ensured by the formation of criteria for the optimality of the proposed system of measures from the position of its effectiveness, time, means, effort, implementation of the selected options under almost equal conditions, comparison of the effectiveness of all stages of the experiment, etc.

The results of the questionnaire, as a reflection of students' opinion, contain info in particular about the organization and conduct of physical education classes:

1. Conducting current online classes on schedule and their availability.

2. Quality of online classes, expedient methods of physical education.

3. Availability of educational and methodological complexes of discipline "Physical education", filled in accordance with the requirements, as well as their availability to students.

4. Influence of physical education by means of distance technologies on the lifestyle of students, on the formation of motivation to counteract forced motor activity.

5. Impact of physical education on overcoming fatigue from hard mental work and leisure with health benefits.

\section{Statistical analysis}

Methods of mathematical statistics were used to analyze the sets of empirical data obtained. Statistical processing of the data was carried out on a computer using the standard STATISTICA 7.0 programs.

\section{Results}

First of all, it should be noted that the study was substantiated by the fact that according to the Article 26 of the Law of Ukraine "On Higher Education" in the higher education institutions (personality is formed "through patriotic, legal, environmental education, affirmation of moral values, social activity, civic position and responsibility, a healthy lifestyle" (Ivashchenko \& Khudolii, 2011). Therefore, the purpose of the implementation of physical education at the university is a multi-special application of all its potency. The latter involves a healthy lifestyle, which requires compliance with certain rules that ensure the harmonious development, high efficiency, spiritual balance and health of students in quarantine (Bezgrebelna, Pavlos, Bulatov, \& Nezgoda, 2020).

According to the results of the questionnaire, it was found out that the vast majority of students surveyed $(81.3 \%)$ believe that physical education classes by means of distance technologies are necessary in the conditions of implementation of quarantine safety measures (Fig. 1).

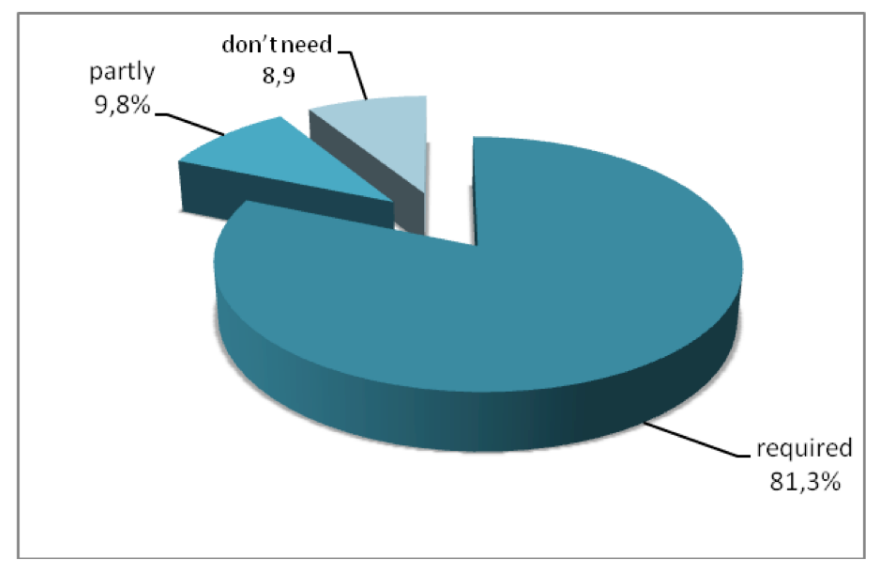

Fig. 1 Results of questionnaire on the need for physical education by means of distance technologies

The analysis of the results of the questionnaire shows that students are generally satisfied with the content of classes. At the same time, $89.1 \%$ of students are convinced of the need to implement into the educational process on physical education of educational-and-methodical complexes in various sports available under such conditions (yoga, stretching, etc.). $51.6 \%$ of students noted that methodical skills gained during classes significantly helped them in organizing independent physical training classes.

The survey found that the vast majority of respondents have a holistic idea of a healthy lifestyle. Thus, $82 \%$ of respondents consider this concept as a set of factors: physical education, regular sports, nutrition, lack of bad habits. $71 \%$ of them support the possibility of physical education by means of distance technologies to counteract the forced limitation of motor activity. At the same time, $26 \%$ of respondents invest in the concept of "basics of a healthy lifestyle" regular classes in the chosen sport, 35\% - the absence of bad habits, $11 \%$ students consider sufficient and proper nutrition.

When asked whether physical education classes in a distance format contribute to obtaining the knowledge about the principles of a healthy lifestyle, the vast majority of students ( $81 \%$ of respondents) said that in this way they received 
new information about this. As a result, $77 \%$ try to follow them from time to time, only $12 \%$ of respondents always follow them and $11 \%$ of respondents do not care about health problems at all (Fig. 2).

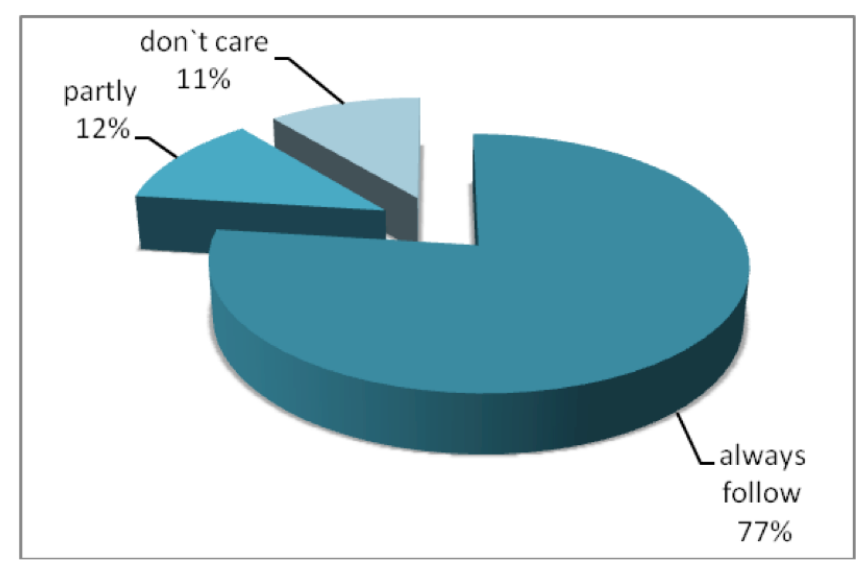

Fig. 2 Distribution of students' responses to promoting physical education in a distance format to gain knowledge about the principles of a healthy lifestyle

\section{Discussion}

The most important factors that actualized scientific searches in the field of higher education, there is a deep understanding of the phenomenon of physical education as a factor of health saving and the urgent need to meet the challenges of today (Ivashchenko \& Khudolii, 2011). Ensuring the effectiveness of physical education of students while on the quarantine requires new approaches and methods of interaction with students, adequate choice of goals and tasks, organizational forms, methods and means of physical education to maintain the proper level of their motor activity and preventing social maladaptation. Our study is consistent with scientific information (Shuba \& Shuba, 2017; Fedorenko, Velichko, Stepkin, Chorna, \& Solovyov, 2019), that using the capabilities of modern technologies that ensure information delivery online on the basis of ICT use, is the main strategic direction of development of the physical education system in higher education. In this way, it is possible to intensify the transition of the educational sphere of physical education of universities students to the innovative way of development.

Therefore, we support scientific approaches that improve the health of young people, as evidenced by the world experience (Pekmezovic, Popovic, Tepavcevic, Gazibara, \& Paunic, 2011), perhaps by forming a healthy lifestyle among this category of population, improving their physical education system aimed at improving social, mental, emotional and physical dimensions.

The national doctrine of educational development of Ukraine in the 21st century states that the main factor in ensuring the development of education should be innovative activities in educational institutions (Bykov, 2010; Bykov, Spirin, \& Pinchuk, 2020). There are opinions (Gevko, Nevmerzhytska, 2019; Bezgrebelna, Pavlos, Bulatov, \& Nezgoda, 2020) that an adequate and the only possible answer to the challenges of our time is the use of distance technologies to effectively implement the physical education of students. We support scientific approaches (Bergier, Tsos, \& Bergier, 2014; Silverman, 2011; Zelenskyi \& Zelenskyi, 2018), one of the key problems is the proper organization of physical and health activities of students for their health preservation in conditions of extremely limited motor activity. Like other scholars, we believe that the need for such a thing arises in connection with the introduction of changes in the content and technology of the educational process, which is fully consistent with the National Strategy for the Development of Education in Ukraine for the period until 2021, where it is determined that modernization and development of education should acquire a outrunning continuous character (Bykov, Spirin, \& Pinchuk, 2020; Shuba \& Shuba, 2017).

Higher education has always been a center of innovative progress (Bykov \& Ovcharuk, 2005). The main task of using distance technologies in the process of physical education is intensification of the educational process, to increase its efficiency and quality, and, therefore, ensure the implementation of social services commissioning of the informatization of society (Gevko, \& Nevmerzhytska, 2019). In the context of global restructuring in all fields of education and taking into account the need for modernization to meet the challenges of time, the transition to new educational services involves a new level of quality and efficiency of physical education of students. Integration of distance technologies into the process of physical education creates the preconditions for radical renewal of both the content-target and technological sides of this process, which is manifested in the substantial enrichment of the system of didactic techniques, means of physical education to meet the challenges of our time.

In the context of the implementation of quarantine safety measures, physical education in higher education undergoes radical changes, which is reflected in global domestic realities. Effective assimilation of the content of physical education is facilitated by the use of the latest ICT on the basis of an interdisciplinary approach, the basis for which is the integration of such technologies into the educational process. Distance education technologies, as means of accumulation, organization, preservation, processing, transmission and dissemination of information, expands the knowledge of students and develops their ability to solve problems of knowledge acquisition and development of the need for a healthy lifestyle. We support the scientific approaches (Bezgrebelna, Pavlos, Bulatov, \& Nezgoda, 2020; Morze \& Kocharian, 2014) that the use of distance technologies takes a prominent place in the educational process of physical education of the higher school. We believe that a step towards the development of physical education of students in this direction is the introduction of interdisciplinary and project approaches, which becomes an integral part of the modern innovative paradigm, that is, modernization of both scientific reflection and practice of physical education in higher education. This approach is focused on the introduction of scientific achievements in physical education and dissemination of the best practices of informatization as a factor in ensuring the effectiveness of this process (Kiv \& Shyshkina, 2019; Kachan, 2017; Klopov, 2013).

In general, our study is consistent with the information that an important role in the creation and use of distance technologies belongs to the higher education system as the main source of highly qualified personnel and a powerful base of fundamental and applied scientific (Bykov, Spirin, \& 
Pinchuk, 2020; Gevko \& Nevmerzhytska, 2019). The specificity of higher education is that it is, on the one hand, a consumer, and on the other hand - an active producer of ICT. It is noted (Shuba \& Shuba, 2017) that the success of educational programs is impossible without the use of ideas and provisions of modernization in the formation and implementation of their content. The last question remains very important in terms of ensuring the quality of the educational process in physical education.

Understanding the main trends in the development of education, relevant modern social development, the mechanisms of their implementation allows for deep analysis of educational processes, and, consequently, identifying opportunities to improve the efficiency of this process and create a basis for the successful integration of the domestic education system into the European space. We support the scientific ideas (Armour, 2014; Deasy, Coughlan, Pironom, Jourdan, \& Mcnamara, 2014) that the center of all educational activities should be a specific student and, accordingly, all methods and forms of organization of physical education should be subject to the goals of its comprehensive personal and professional development. The possibilities of innovative distance technologies ensure optimization of the impact of physical education on the student's personality (Gevko \& Nevmerzhytska, 2019; Kachan, 2017).

\section{Conclusions}

Society's demands for physical activity of university graduates presuppose its most rapid development, largely due to the need to ensure high efficiency in education or employment in the future and hostilities in the east of the country. At the same time, the real state of motor activity of high school students is significantly lower than necessary, and one of the leading reasons now is the restriction of their motor activity in the conditions of quarantine safety measures.

In the course of the study, the analysis of the state of physical education at the university by means of distance technologies was conducted. From the study, we can conclude that such physical education is in a state of development. The results of the study allowed generalizing that the use of distance technologies in physical education of students ensures the formation of valuables of a healthy lifestyle and maintaining their health at the appropriate level. The implementation of distance education as a new form of creating a health-saving educational environment can solve a number of urgent problems:

- taking into account individual psychological characteristics (perception, memory, thinking) and individual pace of perception of educational material;

- visibility of recommendations for coverage of video materials on the organization of motor activity of students at home during quarantine;

- the idea of the formation of motivation for physical activity about the approaches to the formation of the content of physical activity, taking into account the peculiarities of growth and development of the individual's systems of the body;

- possibility to ensure individual orientation of classes, optimization of the content of physical activity and their dosage;
- laying out a large amount of information along with ensuring a personally oriented approach to its use;

- $\quad$ presentation of a large amount of information along with providing a personality-oriented approach to its use;

- presentation of information in the form of completed task;

- $\quad$ providing students with the opportunity to monitor the indicators of individual development, to predict possible changes in health and to carry out appropriate psychological, pedagogical, correctional, rehabilitation measures to maintain their health.

Taking into account all of the above, the introduction of innovative distance technologies in the process of physical education of students, first of all, should be focused on the development of interest, formation of skills and related special knowledge of health saving.

The purpose of education in the conditions of forced selfisolation of students is to create a stable motivation for a healthy lifestyle, to form a need for physical self-improvement as an update to the content of physical education, to create a new educational space, to implement forms and methods of organizing this process by means of distance technologies. The latter is considered as a modern educational environment, comfortable, safe and convenient for all participants in physical education, which has all the potential to ensure the effectiveness of the process of physical education.

The importance of the research results presented is that they are the basis for further improvement of teaching discipline "Physical Education" in the conditions of transition to distance learning in order to solve the problem of maintaining and strengthen the health of students, to create an atmosphere of health preservation in the system of their education.

The survey creates real tools for ensuring and developing the quality of physical education by means of distance technologies. In the future, it will provide an opportunity to extend the acquired experience to other Ukrainian higher educational institutions. Thus, the processing of the results obtained during the questionnaire allows us to state that the task of maintaining, preserving and strengthening the health of students requires attention and development of a system of measures based on the use of the potential of the academic environment of higher education institutions, in particular, pedagogical means that enable informing, learning and education, aimed at acquisition of knowledge, forming and developing skills and abilities to lead a healthy lifestyle, developing value attitudes to their own health in all its manifestations, spheres, levels.

Promising directions of further scientific researches include improvement of the methodology for developing value attitude to their own health in high school students in the process of physical education by means of distance technology.

\section{Conflict of interest}

The authors state no conflict of interest.

\section{References}

Bezgrebelnaya, O., Pavlos, R., BulatovA., \& Nezhoda, S. (2020). Activation of innovative means of physical education of 
students of higher education institutions. Scientific Journal of National Pedagogical Dragomanov University. Series 15. Scientific and Pedagogical Problems of Physical Culture (Physical Culture and Sports), (5(125), 21-25. https://doi.org/10.31392/NPU-nc.series15.2020.5(125).03 (in Ukrainian)

Koryahin, V., Blavt, O., \& Tsiovkh, L. (2018). Regulation of Pedagogical Principles of Control in Physical Education of Students of Special Medical Groups. Theory and Methods of the Physical Education, 18(1), 3-11. https://doi.org/10.17309/tmfv.2018.1.01

Bergier, B., Tsos, A., \& Bergier J. (2014). Factors determining physical activity of Ukrainian students. Annals of Environmental Medicine, 21(3), 613-616. https://doi.org/10.5604/12321966.1120612

Kensitskaya, I. (2017). Model of formation of values of a healthy way of life of students in the course of physical education. Theory and Methods of Physical Education and Sports, 4, 69-76.

Daskapan, A., Tuzun, E.H., \& Eker, L. (2005). Relationship between physical activity level and health related quality of life among university students. Saudi Medical Journal, 26, 1026-1028.

Gladoschuk, O.G. (2018). Higher educational institution as an environment for the formation of physical culture and health self-organization of student youth. Scientific Bulletin of Uzhhorod National University. Series: Pedagogy. Social Work, 1, 292-295. https://doi.org/10.24144/2524-0609.2018.42.292-295

Anikieiev, D.M. (2015). Criteria of effectiveness of students' physical education system in higher educational establishments. Physical education of students, 19(5), 3-8. https://doi.org/10.15561/20755279.2015.0501

Pekmezovic, T., Popovic, A., Tepavcevic, D.K., Gazibara, T., \& Paunic, M. (2011). Factors associated with health-related quality of life among belgrade university students. Quality of Life Research, 20, 391-397. https://doi.org/10.1007/s11136-010-9754-x

Dukh, T. (2011). Group motivation of students in physical education under mutual learning. Teoriâ ta Metodika Fizičnogo Vihovannâ, 11, 38-43. https://tmfv.com.ua/journal/article/view/837 (in Ukrainian)

Extremera, N., \& Fernández-Berrocal, P. (2006). Emotional intelligence as predictor of mental, social, and physical health in university students. Spanish Journal of Psychology, 9(1), 45-51. https://doi.org/10.1017/S1138741600005965

Fedorenko, O., Velichko, V., Stepkin, A., Chorna, A., \& Solovyov, V. (2019). Informatization of education as a pledge of the existence and development of a modern higher education. Educational Dimension, 52, 5-21. https://doi.org/10.31812/pedag.v52i0.3773 (in Ukrainian)
Gevko, I., \& Nevmerzhytska, O. (2019). The role of information and communication technologies in the modern concept of distance learning. Youth and the Market, 2(169), 4145. https://doi.org/10.24919/2308-4634.2019.162711 (in Ukrainian)

Zelenskyi, B., \& Zelenskyi, R. (2018). Motivation: Attitude of Students of Higher Education Institutions of the III Accreditation Levels Toward Physical Education Classes. Teoriâ ta Metodika Fizičnogo Vihovannâ, 18(3), 114-125. https://doi.org/10.17309/tmfv.2018.3.02

Ivashchenko, O.V., \& Khudolii, O.M. (2011). Discipline "General foundations of the theory and methods of physical education". Evaluation criteria. Message II. Theory and methods of physical education, 12, 19-34. https://www.tmfv.com.ua/journal/article/view/758

Shuba, L., \& Shuba, V. (2017). Modernization of physical education of student youth. Physical education of students, 21(6), 310-316. https://doi.org/10.15561/20755279.2017.0608

Bykov, V., Spirin, O., \& Pinchuk, O. (2020). Modern tasks of digital transformation of education. Unesco Chair Journal "Lifelong Professional Education in the XXI Century" (1), 27-36. https://doi.org/10.35387/ucj.1(1).2020.27-36

Bykov, V.Yu. (2010). Modern Problems of Informatization of Education". Information Technologies and Learning Tools, 1(15). (in Ukrainian)

Silverman, S. (2011). Teaching for student learning in physical education. J Phys Educ Recreat Dance, 82, 29-34.

Morze, N., \& Kocharian, A. (2014). ICT competence standards for higher educators and quality assurance in education. Information Technologies and Learning Tools, 5. (in Ukrainian)

Kiv, A. \& Shyshkina, M. (2019). Proceedings of the 7th Workshop on Cloud Technologies in Education (CTE 2019). CEUR Workshop Proceedings, 2643, Available at SSRN: https://ssrn.com/abstract $=3661502$

Kachan, O.A. (2017). Implementation of innovative technologies in physical culture and sports activities of educational institutions. Slavyansk: Vytoky, 138. (in Ukrainian)

Klopov, R.V. (2013). Practical aspects of development and application of distance learning courses in higher physical education. Bulletin of Chernihiv State Pedagogical University T. H. Shevchenko, 3(112), 39-44. (in Ukrainian)

Armour, K. (2014). New Directions for Research in Physical Education and Sport Pedagogy. Sport, Education and Society, 19(7), 853-854. https://doi.org/10.1080/13573322.2014.899493

Deasy, C., Coughlan, B., Pironom, J., Jourdan, D., \& Mcnamara, P.M. (2014). Psychological distress and lifestyle of students: implications for health promotion. Health promotion international, 30(1), 77-87. https://doi.org/10.1093/heapro/dau086 


\title{
РОЗВИТОК ДИСТАНЦІЙНИХ ТЕХНОЛОГІЙ У ФІЗИЧНОМУ ВИХОВАННІ СТУДЕНТІВ: МОЖЛИВОСТІ ТА ВИКЛИКИ
}

\author{
Віктор Корягін $^{1 \mathrm{ABCD}}$, Оксана Блавт ${ }^{1 \mathrm{ABCD}}$ \\ ${ }^{1}$ Національний університет «Львівська політехніка» \\ Авторський вклад: А - дизайн дослідження; В - збір даних; C - статаналіз; D - підготовка рукопису; Е - збір коштів \\ Реферат. Статья: 7 с., 2 рис., 24 джерела.
}

Мета дослідження - виявити стан викладання дисципліни «Фізичне виховання» засобами дистанційних технологій в університеті.

Матеріали і методи. У дослідженні приймали участь 3726 студентів Національного університету «Львівська політехніка» першого курсу усіх навчально-наукових інститутів. Організація дослідження була спрямована на вивчення думки студентів з різних питань щодо якості дистанційного навчання із фізичного виховання На емпіричному рівні дослідження застосовано анкетування.

Результати. В ході дослідження було проведено аналіз стану фізичного виховання в університеті засобами дистанційного навчання. За результатами проведеного анкетування з'ясовано, що переважна більшість опитаних студентів (81,3\%) переконані, що заняття фізичного виховання засобами дистанційного навчання необхідні в умовах запровадження карантинних заходів безпеки. 51,6\% студентів зазначили, що методичні навички, отримані у процесі занять, суттєво допомогли їм під час організації самостійних занять із фізичної підготовки під час призупинення навчальної діяльності в авдиторіях. 71\% підтримують можли- вість занять фізичним вихованням засобами дистанційних технологій задля протидії вимушеному обмеженню рухової активності.

Висновки. Забезпечення ефективності фізичного виховання студентів в положенні запровадження карантинних заходів, вимагає нових підходів та методів взаємодії зі студентами, адекватного вибору мети і завдань, організаційних форм, методів і засобів фізичного виховання задля створення можливості підтримки належного рівня їхної рухової активності та запобіганню явищам соціальної дезадаптації. 3 дослідження можемо зробити висновок, що заняття із фізичного виховання засобами дистанційних технологій знаходиться у стані розвитку, проте не такими швидкими темпами. Натомість, на підставі проведеного дослідження узагальнено, що саме використання у фізичному вихованні студентів засобів дистанційного навчання забезпечує формування у студентів цінностей здорового способу життя та підтримки свого стану здоров'я на відповідному рівні.

Ключові слова: фізичне виховання, студент, дистанційні технології, карантин.

\section{Information about the authors:}

Koryahin V.: koryahinv@meta.ua; https://orcid.org/0000-0003-1472-4846; Department of Physical Education, Lviv Polytechnic National University, Bandera St, 12, Lviv, 79013, Ukraine.

Blavt O.: oksanablavt@ukr.net; https://orcid.org/0000-0001-5526-9339; Department of Physical Education, Lviv Polytechnic National University, Bandera St, 12, Lviv, 79013, Ukraine.

Cite this article as: Koryahin, V., \& Blavt, O. (2021). Development of Distance Technologies in Physical Education of Students: Opportunities and Challenges. Journal of Learning Theory and Methodology, 2(1), 5-11. https://doi.org/10.17309/jltm.2021.1.01

Received: 15.01.2021. Accepted: 05.02.2021. Published: 08.02.2021

This work is licensed under a Creative Commons Attribution 4.0 International License

(http://creativecommons.org/licenses/by/4.0). 